\title{
Popper e o espelho de Darwin
}

\section{Popper and Darwin's mirror}

\author{
Maurício de Carvalho Ramos \\ Professor Doutor do Programa de Pós-Graduação Stricto Sensu \\ em Filosofia da Universidade São Judas Tadeu \\ Rua Belém, 181 - apto 93 Vila Alzira \\ 09030-110 Santo André - SP - Brasil \\ maucramos@aol.com
}

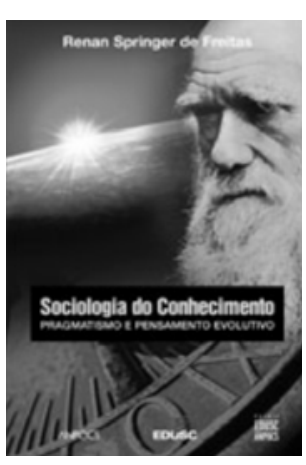

Renan Springer de Freitas

Sociologia do conhecimento. Pragmatismo e

pensamento evolutivo Bauru: Edusc, 2003. 310p.

\begin{abstract}
$\mathrm{A}_{p}^{\mathrm{p}}$ pesar de seu título, Sociologia do conhecimento. Pragmatismo e pensamento evolutivo, a obra do professor Springer de Freitas não oferece uma nova contribuição positiva para o robusto conjunto atual de investigações socioconstrutivistas do conhecimento. Bem ao contrário, o autor promove uma crítica vigorosa dessa abordagem opondo-lhe a perspectiva objetivista popperiana-darwiniana do conhecimento. A crítica também se estende ao pragmatismo, pois os dois pontos de vista entendem, contra a perspectiva objetivista, que o modo mais correto de investigar o conhecimento deve começar pelo estudo do fenômeno sociológico da institucionalização de crenças. Além disso, ao tentarem apoiar essa perspectiva no evolucionismo de Darwin, o socioconstrutivismo e o pragmatismo deturparam o verdadeiro sentido deste último, já que, segundo o autor, herdaram de Hume e de Wittgenstein elementos prédarwinianos que foram incorretamente mantidos como expressão genuína do pensamento de Darwin. Assim, podemos compreender melhor a proposta da obra interpretando seu título, por assim dizer, de maneira invertida: ela oferece uma teoria do conhecimento popperiana-darwiniana 'contra' o pragmatismo e a sociologia do conhecimento.

Contudo, o resultado que Freitas apresenta como original vai além de Popper e do próprio darwinismo 'oficial'. O autor identifica e pretende resolver o que entende como uma insuficiência do esquema popperiano para explicar objetivamente o processo de emergência de problemas a partir da crítica. Pela proposta original de Popper, o conhecimento progride no interior de um mundo autônomo formado pelas teorias e por suas implicações lógicas - o "mundo-3" - de acordo com o seguinte processo: parte-se de um problema original (P1); teorias tentativas (TT) são formuladas para resolver esse problema; ocorre a eliminação de erros (EE) através da crítica e, com a solução do problema inicial, surge um novo problema (P2). Este padrão de evolução cognitiva também teria muito em comum com a evolução das espécies biológicas, pois ambos operam segundo um mesmo processo de proliferação e de correção de erros. As melhores soluções são retidas por forças seletivas que, no caso das espécies, são exercidas pelo ambiente e, no caso das teorias, pela crítica. Assim, as teorias assemelham-se aos organismos, as conjecturas às mutações e a crítica eliminadora de erros à seleção natural. Acrescente-se ainda que essas semelhanças são mais do que meras analogias, pois os próprios organismos são entendidos como "teorias endossomáticas", estruturas físicas naturais que incorporam soluções de problema; as teorias científicas seriam "exossomáticas", estruturas lógico-lingüísticas criadas
\end{abstract}


pelos humanos e que 'habitam' o mundo-3. Somente as teorias mais aptas a espelhar o mundo é que sobrevivem e evoluem, mas a morte de uma teoria endossomática falsa coincide com a morte do organismo, ao passo que as teorias exossomáticas falsas podem morrer com a crítica sem que seus criadores pereçam junto com elas.

Freitas entende que este esquema está correto, mas incompleto, pois não explica como a formulação de teorias e a crítica por ela promovida geram novos problemas (P2), nem como se dá o controle da proliferação de teorias tentativas (TT). Popper teria confiado demais no poder de seleção da crítica e negligenciado os mecanismos que controlariam a produção de conjecturas. Tal lacuna enfraqueceria a identidade entre as evoluções biológica e cognitiva e sujeitaria a explicação do avanço e do crescimento do conhecimento a recorrer a elementos subjetivistas. O que Freitas propõe, então, é ampliar a objetividade e a autonomia do mundo-3 agregando-lhe um novo mecanismo evolutivo, a saber, a "migração de fragmentos de esquemas conceituais". Tal mecanismo resulta de um ajuste do esquema popperiano às tradições de pesquisa de Laudan, que teriam a capacidade de desencadear a emergência de novos problemas e controlar a produção de conjecturas. Quando uma tradição é criticada ocorreria a migração de fragmentos conceituais oriundos de outras tradições que, incorporados, reorganizariam os componentes da tradição inicial. A dinâmica de tradições de pesquisa passa a ser um elemento necessário do processo de evolução do conhecimento.

Contudo, para que o novo mecanismo seja coerente com o processo de evolução biológica, a própria tradição evolucionista darwiniana deve ser criticada, o que é realizado por Freitas aplicando o modelo proposto de migração de fragmentos conceituais. Da mesma maneira que Popper confiou demasiadamente no poder seletivo e regulador da crítica diante da contingência da geração de conjecturas e de problemas, o darwinismo atribuiu um papel excessivo à seleção natural para explicar como as espécies vieram a existir a partir de mutações aleatórias do genoma. Aplicando então seu novo mecanismo, Freitas pretende corrigir a tradição darwiniana incorporando-lhe fragmentos conceituais oriundos de uma tradição de herança kantiana, a saber, a "morfologia racional". O argumento é desenvolvido examinando um conjunto enorme de elementos, mas tratarei apenas do que me pareceu mais fundamental, a saber, o confronto entre os conceitos de organismo presentes em cada uma das tradições, a kantiana e a darwiniana.

Segundo Freitas, a inadequação da idéia de organismo que Darwin herdou da teologia natural fora corrigida no desenvolvimento ulterior da tradição darwiniana pela incorporação do conceito de organismo de Weismann. Definindo-o como uma "totalidade expressiva", o organismo é ao mesmo tempo uma unidade funcional, onde cada parte opera tendo em vista as demais, e uma dualidade estrutural, composta pelos plasmas somático e germinativo; como é bem conhecido, essa dualidade levou à negação da herança dos caracteres adquiridos. Mas, além disso, o plasma somático é o elemento passivo que apenas expressa a atividade do plasma germinativo. Traduzindo essa dualidade nos termos da genética atual, a ação do genoma (o germe) é a causa mais 
fundamental da expressão das principais características orgânicas (o soma). O genoma não é, de fato, uma 'parte' do organismo, mas sua agência diretora central e externa. Mais concretamente, trata-se da "visão canônica em genética molecular": o DNA determina a estrutura e a atividade celular como um conjunto completo de instruções para a síntese de proteínas. Esta visão é o alvo principal da crítica de Freitas que, sem entrar aqui nos detalhes, é julgada insuficiente para explicar toda a gama de estruturas e funções orgânicas (um dos pontos examinados diz respeito à incapacidade da informação genética em determinar as estruturas secundárias, terciárias e quaternárias das proteínas). Por fim, as mutações do genoma seriam passivamente expressas pelo organismo e, assim, a seleção natural não poderia explicar sozinha a diversidade de espécies diante de tamanha variação aleatória. Todos esses problemas, em maior ou menor grau, decorrem da centralidade que a visão canônica da genética assumiu na tradição darwiniana.

A tradição kantiana da morfologia racional a que Freitas recorre para resolver as insuficiências aqui sumariadas define o organismo como um "todo auto-organizante". Ao contrário da concepção anterior, aqui o organismo é uma totalidade funcional "e estrutural": todas as partes orgânicas, além de operarem umas em função das outras, também são geradas umas pelas outras. Partindo diretamente para a expressão contemporânea do conceito, ele traduz-se em modelos de auto-organização que integram o DNA e as proteínas como partes igualmente ativas de um sistema genético maior capaz de explicar a produção, a manutenção e a evolução dos sistemas biológicos. A dualidade soma-germe desaparece e o genoma deixa de ser uma agência organiza-dora central externa para tornar-se uma parte real do sistema. Com isso, as mudanças aleatórias do genoma são reguladas por outras partes do sistema e criam um leque de possibilidades que preserva a integridade estrutural do organismo. É sob esse leque de variações previamente determinadas e ordenadas que a seleção natural atuará, e não sob a expressão das mutações aleatórias do genoma. Assim, Freitas propõe que se esse conceito de organismo for incorporado à tradição darwiniana ele deslocará a visão canônica da genética para sua periferia e, com isso, poderá resolver as deficiências antes apontadas.

Com isso obtém-se por fim o resultado inicialmente pretendido: tornar a tradição darwiniana um guia adequado para explicar a evolução do conhecimento. Assim reformada, essa tradição pode explicar a evolução biológica a partir da dinâmica interna de sistemas biológicos auto-organizantes e, da mesma maneira, a evolução do conhecimento pode ser explicada pela dinâmica das tradições de pesquisa que também se auto-organizariam através dos rearranjos provocados pela migração de esquemas conceituais.

Esta descrição captura apenas os aspectos da obra que julguei teoricamente centrais, e espero que minha seleção e a necessidade de concisão não tenham deformado as idéias originais do autor cuja elaboração e aplicação contou com o exame minucioso de muitos outros temas e autores que não mencionei. Diante dessa diversidade torna-se difícil avaliar globalmente o mérito da obra, sobretudo se ela consegue ou não 
promover um progresso na epistemologia evolutiva de Popper. Entretanto, o que me parece bastante claro é que o livro de Freitas é inteiramente fiel ao espírito que o anima: a solução dos problemas que ele propõe certamente gerará muitos outros que poderão estimular a crítica ou a colaboração de várias tradições de pesquisa em epistemologia. Isso me parece suficiente para fazer de Sociologia do conhecimento uma obra que vale a pena ser lida. Proponho a seguir alguns comentários finais para duas questões que talvez possam ser objeto de futuros debates.

Como bem apontaram os críticos com que Freitas debate, a perspectiva objetivista que ele amplia e à qual adere corre o sério risco de precipitar-se na direção de um "etnocentrismo cego". Se as culturas que engendram conhecimentos capazes de sobreviver mais tempo no mundo-3 são as que contribuem para sua evolução, e se a cultura científica ocidental é a que tem crescentemente mais contribuído nesse sentido, ela torna-se um parâmetro cognitivo 'natural' para todas as outras culturas. Mas, como já aconteceu muitas vezes, esse mesmo parâmetro pode ser facilmente aplicado na produção de alguma forma de hierarquia evolutiva das próprias culturas e das pessoas que as integram. Confrontadas com a cultura científica ocidental, as chamadas culturas tradicionais ainda existentes poderão ser reduzidas a meros 'fósseis vivos' que estão necessariamente com seus dias contatos. Não estou afirmando que Freitas chegue a isso, mas a simples existência dessa possibilidade torna bastante razoável o exame da hipótese alternativa de que a autonomia e a objetividade de um mundo-3 ou de estruturas análogas acabem funcionando como a reificação de um processo que é, na realidade, histórico e social.

Não me parece ser pouca coisa nem de pouco valor o que se pode perder quando afastamos demais os sujeitos do processo de construção da ciência. Mas também concordo com Freitas quando ele aponta para o fato indesejável de as perspectivas socioconstrutivistas e pragmáticas tornarem o conhecimento refém de processos cada vez mais restritos, tanto no tempo como no espaço das instituições e das comunidades, levando à progressiva redução das possibilidades de entender o avanço do conhecimento dentro de uma perspectiva histórica global e universal. O que essa perspectiva local, à qual Freitas confere o sugestivo nome de "visão paroquial do conhecimento", proíbe conhecer também não é de pouco valor. Para mencionar apenas um exemplo relativamente evidente, esvaziar totalmente de sentido a idéia de conhecimento objetivo pode tornar difícil a defesa do conhecimento como um bem social da humanidade contra as conhecidas tentativas atuais de torná-lo de uso cada vez mais restrito de grupos protegidos por patentes ou direitos de propriedade intelectual. Tendo em vista essas tensões, Sociologia do conhecimento também pode ser caracterizado como um fecundo acesso ao confronto entre "etnocentrismo e paroquialismo" como abordagens antagônicas do conhecimento.

A segunda questão que quero comentar focaliza diretamente as dificuldades envolvidas na integração dos processos de evolução biológica e cognitiva. O postulado popperiano da existência de um mundo-3 autônomo de teorias e suas implicações lógicas em evolução criam uma espécie de dualidade 'parcial'. Há uma continuidade das evoluções bioló- 
gica e cognitiva quanto à lógica do processo - a retenção seletiva das conjecturas que apresentam melhores soluções de problemas ou, pela proposta de Freitas, das tradições de pesquisa que se auto-organizam de modo mais promissor. Mas também está correto afirmar que as chamadas teorias endossomáticas e exossomáticas são descontínuas sob muitos aspectos, já que as primeiras convergem no sentido de espelhar o mundo enquanto formas mais ou menos bem adaptadas ao ambiente biológico e físico, e as segundas convergem para a verdade enquanto formas mais ou menos adaptadas ao 'ambiente lógico' do mundo-3. Quando os humanos começaram a produzir ciência, passaram a criar o mundo-3 no qual as teorias poderiam evoluir constrangidas por um mundo de possibilidades lógicas independentes do nascimento e do crescimento dos próprios organismos. É esse o sentido de dualismo 'parcial': as teorias exossomáticas são uma extensão das endossomáticas enquanto soluções de problemas, mas ambas 'nascem', 'vivem' e 'morrem' em ambientes ou mundos bem distintos.

Assim, apesar de todo o esforço de Freitas em inserir num mesmo contínuo as evoluções biológica e cognitiva, penso que ainda há espaço para perguntar: o que há de realmente comum aos espelhos de Popper e de Darwin? Em que medida a convergência adaptativa dos organismos ao ambiente físico e a convergência para a verdade das teorias exossomáticas ao ambiente lógico espelham a mesma realidade? Tais diferenças não se refletiriam nos próprios processos evolutivos? Parece-me que Popper enfrentou tais questões respondendo afirmativamente a esta última questão. No capítulo 7 de Conhecimento objetivo, ele diz que a evolução biológica segue o modelo clássico de uma árvore ascendente no tempo, na qual as diversas espécies representam soluções cada vez mais especializadas ou diferenciadas de enfrentar os desafios ambientais. No tronco e em suas ramificações maiores encontram-se os ancestrais (as teorias endossomáticas menos especializadas), e nas extremidades dos ramos encontra-se a diversidade de espécies viventes (para um determinado corte no tempo). Contudo, a evolução do conhecimento teorético (o conhecimento aplicado segue o mesmo padrão evolutivo arborescente das espécies) exibe um padrão semelhante a uma árvore 'invertida': os ramos surgem 'do nada' e vão convergindo em um tronco comum rumo a uma tendência de teorias cada vez mais unificadas. Assim, parece-me que os organismos das várias espécies espelham o ambiente de maneiras diversas, estando especializadamente adaptados a diversos nichos ecológicos e não a uma única 'realidade'. Se somarmos a essa especialização adaptativa das espécies o fato de elas estarem reprodutivamente isoladas, vemos aumentar a descontinuidade também entre elas, mesmo que sejam garantidamente contínuas pelo postulado da descendência comum. Ao contrário, as teorias exossomáticas são realmente contínuas em todos os sentidos, pois elas convergem unificadamente para a verdade e, para tanto, devem espelhar sempre uma mesma realidade. Em resumo, teorias endo e exossomáticas são muito semelhantes enquanto produtos de tentativas experimentais de solucionar problemas, mas são bem diferentes quanto à natureza dos problemas enfrentados, ao modo de solucionálos, aos resultados advindos do sucesso ou do fracasso em resolvê-los e à maneira pela qual espelham seus ambientes particulares. 
Creio que a perspectiva popperiana de Freitas possui uma maneira peculiar de manter a continuidade entre as teorias exossomáticas e endossomáticas e destas últimas entre si, apesar das diferenças aqui já apontadas. Falando de modo bastante sumário, a diversidade de nichos ecológicos é reduzida a uma estrutura algo semelhante à do mundo-3: o ambiente biofísico seria constituído por 'nichos lógicos' que representam conjuntos de possibilidades adaptativas a serem exploradas experimentalmente pelos organismos, mas que se integram e são regulados pelo conjunto das leis naturais. Isso permite que as várias espécies, apesar de suas especializações adaptativas, ofereçam respostas a problemas propostos por um mesmo mundo. É por isso que a convergência adaptativa, que pelo darwinismo oficial é uma espécie de 'ruído' que atrapalha a compreensão da evolução (ela determina analogias funcionais que podem ser confundidas com o efeito da ancestralidade comum), passa a ser de grande valor heurístico para a evolução da própria perspectiva reformada da tradição darwiniana que Freitas oferece. Embora não possa aqui me estender no assunto, eu ousaria especular, usando os próprios termos de Freitas, que até mesmo o isolamento genético das espécies e a negação da herança de caracteres adquiridos (dois outros postulados que, junto com a visão canônica da biologia molecular, podem ser localizados na concepção weismanniana de organismo) também seriam empurrados para a periferia da tradição darwiniana, caso ela incorporasse uma concepção sistêmica de organismo. Como todo auto-organizante local o organismo integra-se muito mais facilmente ao todo universal - a própria realidade - do que faz o organismo como totalidade expressiva, cuja agência diretora gené-tica central pode estar apartada não apenas do organismo como, exagerando um pouco, do próprio mundo (quero dizer que sem a idéia de auto-organização a origem do sistema genético seria um 'milagre'). Assim, se a idéia de auto-organização puder oferecer cidadania à noção de convergência adaptativa no interior da tradição darwiniana, outras semelhanças, além da solução de problemas, poderão ser estabelecidas entre a evolução biológica e a cognitiva, entre o ambiente biofísico e o ambiente de mundo-3, enfim, entre os espelhos de Popper e de Darwin.

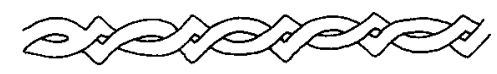

